University of Pennsylvania Carey Law School

Penn Law: Legal Scholarship Repository

Faculty Scholarship at Penn Law

$1-31-2010$

\title{
Intra-Enterprise Activity, Joint Ventures and Sports Leagues: Identifying Unilateral Conduct Under the Antitrust Laws
}

Herbert J. Hovenkamp

University of Pennsylvania Carey Law School

Follow this and additional works at: https://scholarship.law.upenn.edu/faculty_scholarship

Part of the Antitrust and Trade Regulation Commons, Entertainment, Arts, and Sports Law Commons, Industrial Organization Commons, Intellectual Property Law Commons, and the Law and Economics Commons

\section{Repository Citation}

Hovenkamp, Herbert J., "Intra-Enterprise Activity, Joint Ventures and Sports Leagues: Identifying Unilateral Conduct Under the Antitrust Laws" (2010). Faculty Scholarship at Penn Law. 1812.

https://scholarship.law.upenn.edu/faculty_scholarship/1812

This Article is brought to you for free and open access by Penn Law: Legal Scholarship Repository. It has been accepted for inclusion in Faculty Scholarship at Penn Law by an authorized administrator of Penn Law: Legal Scholarship Repository. For more information, please contact PennlawIR@law.upenn.edu. 


\title{
Intra-Enterprise Activity, Joint Ventures and Sports Leagues:
}

\author{
Identifying Unilateral Conduct under the Antitrust Laws
}

Herbert Hovenkamp ${ }^{*}$

While $\S 1$ of the Sherman Act (as well as $\S 3$ of the Clayton Act) require a "contract" or "agreement" between two or more persons, neither statute identifies in significant detail the entities to which its prohibitions refer other than to say that both corporations and natural persons are covered. Historically and today, concerted action by persons within a single corporation is not a "contract, combination...or conspiracy" within the meaning of Sherman Act \$1. For example, when General Motors sets the price of a new model of automobile, its decision almost certainly involves joint deliberation by many biological persons, and perhaps even an "agreement" among them at the conclusion of the meeting. To apply §1's full prohibitions to this "price-fixing," however, would condemn and even criminalize absolutely unitary price setting by a single firm-or single economic actor as far as our markets are concerned. Thus the Supreme Court held in Copperweld that business decisions made within a single firm, even a parent and its subsidiary, must be counted as unilateral acts. ${ }^{1}$

At the same time, at least some decisions of certain organizations-such as trade associations, professional associations, and some joint ventures-are rightfully treated as concerted decisions by the members. For example, the rules promulgated by the California Dental Association, the NCAA, the New York Stock Exchange, the Associated Press, and the National Society of Professional Engineers are regarded not as the unilateral acts of those entities but as the conspiracies of their members.

The courts have had little difficulty in treating organizations created to serve their member-competitors or to regulate their market behavior as continuing agreements of the members. Nor is there any practical problem when we focus on those improprieties reducing competition among the members or with their competitors. But what about the day-to-day operations of the organization? Must we also see the trade association's buying, selling, hiring, renting, or investing decisions as continuing conspiracies among the members? For example, is a trade association's decision to have its annual convention in New York rather than Missouri a "concerted refusal to deal" with Missouri? To be sure, an affirmative answer would seldom bring legal liability, because few such associations have any significant share of the markets in which they hire employees, buy supplies, rent offices, invest funds, or sell services to the public. Even in the presence of power, most such decisions are "reasonable" as far as antitrust is concerned, and thus lawful. Nevertheless, all of these decisions

\footnotetext{
*Ben v. \& Dorothy Willie Professor of Law, University of lowa.

${ }^{1}$ Copperweld Corp. v. Independence Tube Corp., 467 U.S. 752 (1984).
} 
Feb., 2010

become subject to Sherman Act $\S 1$ litigation if they are conspiracies. General allegations of nontrivial market shares within the very narrow markets that are often alleged would be sufficient to survive a dismissal or even a summary judgment motion before discovery. One might respond to this concern in three ways: ignore it, adjust the necessary allegations or proofs, or hold such organizations to be continuing conspiracies for some purposes but single entities for other purposes.

Although it lacks precise meaning or antitrust consequence, "joint venture" usually refers to a research, production, or marketing enterprise created by several persons other than ordinary investors. The creators may be actual competitors, potential competitors, potential buyer and seller, or otherwise in "related" businesses. Obviously, the most significant competitive threats arise when joint venture participants are actual or potential competitors. A venture's formation results from the founders' "agreement," which, like any other formation agreement, can be appraised for "reasonableness" under Sherman Act §1. Such an agreement among competitors may typically threaten competition more than the presumptively lawful agreement among ordinary investors creating the usual business firm and therefore invites more careful scrutiny. ${ }^{2}$

A joint venture also resembles the more loose-knit trade association of competitors or the even looser-knit simple contract among competitors. Yet it differs from both. Unlike the restraining contract, the venture agreement may not directly limit the future behavior of the founders. Unlike the trade association, whose main activities affect the members' competition among themselves, the main activity of the typical joint venture is research, production, or distribution in its own right. The latter distinction is not a sharp one because a trade association may also do research and produce information, and a joint venture may also limit or affect its parents' marketing behavior. Nonetheless, worth emphasizing is the joint venture's market role, which may be both separate from that of its parents and more like that of the ordinary firm.

The issue considered here is when should such ventures be regarded as a single entity for antitrust purposes and when as a continuing conspiracy among their creators or members. The "single entity" answer seems appropriate for venture activities not governing the members' conduct, while the "continuing conspiracy" answer seems wise for rule-making activities and for those developments that could make continued collaboration unreasonable for the future. The latter conclusion may be qualified for ventures that ought to be regarded as "quasimergers" and left undisturbed.

Antitrust challenges to trade association activities generally seek to enjoin a particular practice and rarely challenge the association's very existence. While this is generally true for joint ventures, the conclusion is less categorical. Some "joint ventures" are in fact little more than fronts for cartels and, having no lawful

\footnotetext{
${ }^{2}$ See 12 Herbert Hovenkamp, Antitrust Law I2101 (2d ed. 2005).
} 
purpose, are properly dissolved by antitrust decree. ${ }^{3}$ Other joint ventures integrate the participants so completely that they are analyzed in the same way as mergers and can thus be enjoined under merger standards of illegality. ${ }^{4}$

\section{Formation and Future Reexamination of the Joint Venture}

Competitors are permitted to collaborate when the threats to competition are either modest or are outweighed by pro competitive considerations. Although usually made case by case, this appraisal is sometimes made for a class, as in the per se condemnation of naked price fixing, which is thought to lack redeeming virtue and to endanger competition severely because it is undertaken only by those who assume they can control the market. ${ }^{5}$ But even the per se categories have exceptions, and what may seem like "price fixing" to the layperson will not always be so classified by the courts. ${ }^{6}$ For example, suppose that firms $A$ and $B$ jointly create firm $C$ to market the one product they make; $C$ sets the price it charges for the product, draws equally on $A$ and $B$ for supplies (up to the point of the ability of each to produce) and returns its net revenues to $A$ and $B$ in proportion to the amounts each supplied. Although $A$ and $B$ have thus ended price competition inter se, the arrangement is not regarded as a pricefixing conspiracy - or at least not the kind of price fixing that is automatically unlawful. The $A-B$ agreement that creates $C$ will be held reasonable when it brings significant cost savings to collaborators with relatively modest market shares. ${ }^{7}$ Unlike a naked price-fixing agreement between those very same firms, the joint selling agreement can achieve the parties' apparent objective-here, socially desirable cost savings-without implying that the collaborators possess market power.

The courts examine not only the immediate harms and benefits of a venture, but also the likely consequences of all that is reasonably necessary to carry it out, the expected ways in which the venture will act vis-à-vis its parents and their competitors, and the probable spillovers on the parents' other activities. Thus, a well-considered decision legalizing the creation of a joint venture necessarily expresses approval of all that is inherent and reasonably ancillary to it. Because it would be senseless for antitrust law to take away with one hand what it gives with the other, approval means that the subsequent realization of that which was foreseeable and judged reasonable at the time of creation must also be legal.

Of course, even if we assume a fully litigated and careful judgment, the original appraisal may be wrong. Or the inherent aspects of the venture or its spillovers may turn out worse than we once reasonably supposed. Or the parties may behave more restrictively than originally seemed likely. In those events, the

\footnotetext{
${ }^{3}$ This was the Supreme Court's characterization of the railroad joint ventures dissolved in United States v. Trans-Missouri Freight Assn., 166 U.S. 290 (1897); and United States v. Joint-Traffic Assn., 171 U.S. 505 (1898).

${ }^{4}$ See 12 Antitrust Law 1 T2121c, 2122

${ }^{5}$ See 7 Antitrust Law $\llbracket \llbracket 1509,1510,11$ Antitrust Law $\llbracket 1910$.

${ }^{6}$ E.g., Broadcast Music v. CBS, 441 U.S. 1 (1979).

${ }^{7}$ See 12 Antitrust Law $\mathbb{1} \mid 2132,2137$.
} 
original formation may later be judged illegal.

To be sure, an argument can be made that a lawful productive venture should be regarded as a partial or quasi-merger among the parents. ${ }^{8}$ Although the legality of the original formation will often be examined later, actual litigation and approval operates as a "legal license." At least some of the reasons for leaving a merger undisturbed by subsequent developments apply to the joint venture as well. Furthermore, exposing such ventures to the peril of later developments may encourage total merger at the outset even though the parties are content with less than total and more competitive partial integration. An added value of the joint venture is that the parents generally remain as important and independent market actors, often in competition with one another with respect to nonventure business.

In any event, under appropriate circumstances, antitrust has the power both to condemn the original formation and to supervise ongoing activities. For example, suppose that two integrated oil companies-each one of which explores, produces, transports, refines, and markets-form a separate company that bids against others for certain exploration rights. The company acquires the rights, drills successfully, and either delivers the resulting oil to its parents or sells it to outsiders. Competition among the parents in bidding has been eliminated through an undoubted agreement, which we will assume to be lawful on a finding that threats to competition are minor or outweighed by risk-sharing virtues. Postexploration effects on the parents' own competitive production decisions will be considered. For example, parental discussions about the venture's output or price might lead to similar decisions by each parent. If this danger seems unacceptable because of the parents' own market shares, the venture will be deemed unlawful at the outset, unless those spillovers can be eliminated by insulating venture decisions from the parents or by providing for operation by only one parent or by requiring that successful wells must be sold back to one parent or the other. And if not made at the outset, such judgments can be made later. Thus, competition can be fully protected without regarding the venture's own decisions as a conspiracy of the parents. Unacceptable spillovers on the parents' competition with each other can be seen as an aspect of the agreement creating the venture and, if not avoidable by altering venture mechanics, could justify dissolution of the venture as unlawful collaboration among the parents.

A similar question might arise in a joint research venture. Initial permission under the antitrust laws would normally reflect a judgment that the parents face enough competition from others to motivate continued research notwithstanding the end of research competition inter se. So long as that situation continues, there is no reason to ask whether the venture has purposely slowed the pace of development. But if the parents come to dominate the industry such that their

\footnotetext{
${ }^{8}$ E.g., United States v. Penn-Olin Chem. Co., 378 U.S. 158 (1964), which subjected the formation of a joint venture company to Clayton Act $\S 7$.

${ }^{9}$ See United States v. United Shoe Mach. Corp., 110 F. Supp. 295, 343 (D. Mass. 1953), aff'd per curiam, 347 U.S. 521 (1954).
} 
Feb., 2010

venture now amounts to industrywide collaboration, the venture itself may have become unreasonable. They may no longer need the venture in order to perform efficient research. Moreover, the venture no longer has the spur of outside competition to motivate "adequate" innovation. Apart from selfincrimination by the collaborators, however, it will seldom be possible to compare actual innovation with what might have been. But if the venture is not regarded as a permanent quasi-merger subject only to Sherman Act §2,and if a remedy is otherwise appropriate, the proper course is dissolution rather than close judicial supervision of joint research operations as a "continuing conspiracy."

\section{Impact on Competitors of Parents}

Suppose that two small firms create a joint research venture that invents the "better mousetrap" but licenses only its parents, who thereby win the market. Here we must be very discriminating about what, if anything, should be brought to an end. Further joint research by these collaborators may become inappropriate but not their retention of the fruits of past lawful joint research. The appropriate result for the future is a very different question from the disposition of the invention.

The reason is clear: the original collaboration was permitted in order to encourage research. Research is encouraged by the prospect of success for those who risk it. The procompetitive objective would be impaired by denying risk bearers the fruits of their venture. The argument is not ironclad. We might conceptualize the venture firm as the separate entity we argue for in other contexts and view the parents as mere investors who can profit when the venture sells its invention to all comers. But the fact is that it was not general investors who created the venture-and nothing prevented rivals or general investors from undertaking similar risks. Of course, if this policy conclusion is sound, it matters not how we conceptualize the transaction for conspiracy purposes. An agreement at the outset between two small firms that they would keep the fruits of the venture to themselves seems as reasonable as the venture itself. Even without such express agreement, exclusive self-use seems entirely foreseeable. Again, therefore, it is not the refusal to license others that is anticompetitive. At most, it is continued collaboration through the joint venture that should be ended.

In Rothery the District of Columbia Circuit was faced with a national van line and storage firm, Atlas, that engaged independent firms to solicit customers and pack and carry goods. ${ }^{11}$ Atlas had certain rules, such as forbidding each affiliated carrier from moving goods for which Atlas received no compensation(except through a separate firm not associated in customers' minds with Atlas). Some of those carriers wished to challenge the limitation as an illegal "boycott," which required finding an agreement. The Atlas board's 11 members included six actual or potential carriers and three officers of Atlas:

\footnotetext{
${ }^{11}$ Rothery Storage \& Van Co. v. Atlas Van Lines, 792 F.2d 210 (D.C. Cir. 1986), cert. denied, 479 U.S. 1033(1987).
} 
Thus, all but two members of the board represented separate legal entities that competed in interstate commerce. This brings the case within the rule of Sealy and Topco and shows the existence of a horizontal restraint. ${ }^{12}$

In the cited cases the central rule-making organization was wholly owned and controlled by the members, who were thus making rules for themselves that affected their nonventure business. The Rothery court emphasized that the firms actually carrying the goods competed with each other and in part with Atlas, and that the rules governing their association, though formally promulgated by Atlas, reflected an understanding among the constituent parts, which remained independent forces in the market to which the Atlas rules applied. This conclusion seems correct even though the affiliated firms did not own Atlas or entirely control it.

Contrast the Greensboro decision, where some 39 rural electric distribution cooperatives created Oglethorpe, a nonprofit electric generation and transmission cooperative, which they owned and whose policies and rates they dictated. ${ }^{13}$ In order to meet their needs and in accordance with various federal policies relating to the financing of rural electrification, the parent cooperatives agreed to purchase most of their energy needs from Oglethorpe. ${ }^{14}$ When these purchasing arrangements were challenged by a would-be seller of power to the distribution co-ops, the court held that they and Oglethorpe constituted a single entity and thus were incapable of conspiring under the Sherman Act. ${ }^{15}$ While the decision of individual members to purchase most of their needs from a commonly owned entity was almost certainly reasonable, we would not have removed it from $\$ 1$ scrutiny by declaring it to be unilateral, for it affected the individual purchasing decisions of the members. ${ }^{16}$

In Hahn the Ninth Circuit thought it relevant to decide whether a health insurance plan should be regarded as a conspiracy of its board members (or perhaps of physicians participating in the plan). ${ }^{17}$ Podiatrists complained that

${ }^{12}$ Id. at 215, citing United States v. Sealy Corp., 388 U.S. 350 (1967); Topco Assocs. v. United States, 405 U.S. 596 (1972).

${ }^{13}$ Greensboro Lumber Co. v. Georgia Power Co., 643 F. Supp. 1345, 1352 (N.D. Ga.1986).

${ }^{14}$ Id. at 1353

${ }^{15}$ Id. At 1367. See also Genetic Sys. Corp. v. Abbott Laboratories, 691 F. Supp. 407, (D.D.C. 1988) (not-for-profit National Red Cross corporation incapable of conspiring with its unincorporated branches, or "regions").

${ }^{16}$ By contrast, the decision in City of Mt. Pleasant v. Associated Elec. Co-op, 838 F.2d 268 (8th Cir. 1988), involved the venture's own pricing of its output. Cf. Sewell Plastics v. Coca-Cola, 720 F. Supp. 1196 (W.D.N.C. 1989), aff'd per curiam, 1990-2 Trade Cas. \69,165, 912 F.2d 463 (4th Cir. 1990, unpublished), cert. denied, 498 U.S. 1110 (1991) (soft drink bottlers built their own bottle-manufacturing facility and agreed to purchase a minimum specified percentage of their bottle needs from it).

${ }^{17}$ Hahn v. Oregon Physicians' Serv., 868 F.2d 1022 (9th Cir. 1988), cert. denied, 493 U.S. 846 (1989). 
they were forbidden "membership" and, although they were reimbursed by the plan, they were reimbursed at lower rates than were physicians who treated the foot. If competing physicians controlled the plan, the court thought they could be engaged in an illegal boycott of the podiatrists. The Ninth Circuit saw the issue as

whether practitioners sharing substantially similar economic interests collectively exercised control of a plan under whose auspices they have reached an agreement which works to the detriment of competitors. ${ }^{18}$

The court apparently thought they did because 90 percent of the board members were practicing physicians at a time when the board limited the reimbursement rate of the complaining podiatrists and because physicians generally perform considerable foot care, though that was not their primary source of income. Even physician board members not doing feet were deemed to have an economic interest aligned with physicians who did.

Once a venture is judged to have been lawful at its inception and currently, decisions that do not affect the behavior of the participants in their nonventure business should generally be regarded as those of a single entity rather than the parents' daily conspiracy. This rule saves the parties and the courts from inconvenient, if not impossible, judicial review of the venture's day-to-day operations at the suit of disappointed suppliers and others and, as we have just seen, does not immunize any seriously anticompetitive conduct resulting from unexpected spillovers or relevant changes in market circumstances.

Organizations such as the New York Stock Exchange and the Associated Press were properly treated as continuing conspiracies of their members to the extent that they made rules for the admission of members' competitors or for the control of the members' nonventure business. But such organizations also do other things. The New York Stock Exchange buys Wall Street property for its offices and contracts with certain manufacturers for the installation of stock quotation computers. The Associated Press buys and rents typewriters and hires reporters and analysts. A joint research venture hires scientists and may be one of the few purchasers of exotic equipment.

Such decisions are seldom attacked under Sherman Act §1, probably because they seem reasonable even if viewed as conspiracies among the members-either because the members lack significant market power in the machine-realty-employee markets or because such collaboration is reasonably inherent in the permitted concert creating the central organization. Occasionally, an unsuccessful effort is made to characterize venture behavior as a per se illegal "boycott" conspiracy. Suppose, for example, that the Associated Press decides to hire only college graduates in its own offices. Though perhaps unwise, such a decision by an individual newspaper would not be of antitrust concern, while a collective decision by several newspapers would be. Let us suppose that

\footnotetext{
${ }^{18} \mathrm{Id}$. at 1029.
} 
Feb., 2010

each individual newspaper continues to decide its own hiring policies unilaterally. Upon a challenge by a would-be employee, the Associated Press should be treated as a single entity, although admittedly one that is controlled by its members. Once we allow the several newspapers to create the Associated Press to gather news, that function will be performed most efficiently by an organization that can operate with the same legal freedoms as the ordinary business entity. Furthermore, it would be socially inconvenient to treat it as a conspiracy whose every act is subject to judicial supervision.

To test that single-entity approach, suppose that the Associated Press were a virtual monopsony ${ }^{19}$ in the market for certain specialized analysts. The judicial temptation to control a monopsonist's "unfair" conduct may grab the $\S 1$ handle provided by the agreement creating the AP; it would be as if the founders had specified that their creature would only hire certain persons. Literacy, knowledge, and sophistication are reasonable objectives, the plaintiffs will say, but the exclusion of nongraduates is overbroad. Unfortunately, the openness and ambiguity of "reasonableness" seemingly invites courts either to substitute their managerial judgments for those of the firm or, as is often demanded of administrative agencies, to require hearings and other "due process" for affected persons. However, the parentage of the Associated Press does not suggest that its management is likely to be less wise or less competitive in the employment market than an AP-like organization created by ordinary investors. Given that we will not dissolve such a useful joint enterprise, we should see its operation as that of a single entity. And if it attains or threatens monopoly power, it will be subject to the same $\S 2$ control as other firms with such power. ${ }^{20}$

\footnotetext{
${ }^{19} \mathrm{~A}$ monopsonist is a monopolist in the market in which it buys. See 2B Phillip E. Areeda \& Herbert Hovenkamp, Antitrust Law $\lceil 574$ (3d ed. 2008)..

20 See Bell v. Fur Breeders' Agricultural Cooperative, 348 F.3d 1224 (10th Cir. 2003), which concluded that an agricultural cooperative owned by fur breeders is a single entity for purposes of a member's complaint that discriminatory policies under which cooperative delivered feed to its members constituted an antitrust violation. The court relied on language in Sunkist Growers, Inc. v. Winckler \& Smith Citrus Products Co., 370 U.S. 19 (1962), treating three corporations that formed into an agricultural cooperative as a single entity, and concluding that the Supreme Court had determined that agricultural cooperatives, like corporations, do not have the plurality of actors necessary for a Section 1"conspiracy." 348 F.3d at 1232-1233. However, numerous cases have refused to apply the Capper-Volstead exemption and have found a $\$ 1$ conspiracy when an agricultural cooperative engages in acts of "boycott" or "intimidation" as opposed to mere price fixing. See, e.g., United States v. Borden Co., 308 U.S. 188 (1939) (finding §1 conspiracy).

See also American Needle, Inc. v. NFL, 538 F.3d 736 (7th Cir. 2008), cert. granted, 2009 WI 1835175 (US Jun. 9, 2009) (for purposes of exclusive licensing agreement to a single apparel manufacturer the NFL should be considered a single entity; and a firm may license either one or multiple licensees at its pleasure); Jack Russell Terrier Network of Northern Cal. v. American Kennel Club, Inc., 407 F.3d 1027 (9th Cir. 2005), holding that, consistent with the allegations in the plaintiff's complaint, a nonprofit association made up of dog breeders (the JRTCA, or Jack Russell Terrier Club of
} 
Feb., 2010

America), many of whom are for-profit entities, should be treated as a single entity:

Assuming all the Appellants' alleged facts to be true, they have not alleged sufficient facts to support a claim that the JRTCA and its affiliates are separate entities pursuing different economic goals, capable of conspiring for Sherman Act purposes. First, regarding the parties' unity of economic interest, the Appellants did not allege in what manner the JRTCA and the JRTCA regional affiliates named as co-defendants had divergent economic interests, or what goals the affiliates pursued other than those of the JRTCA.

Id. at 1036, and noting:

We have held that the single entity rule applies to principal-agent relationships, Calculators Hawaii, Inc. v. Brandt, Inc., 724 F.2d 1332, 1336 (9th Cir. 1983), as well as to an agreement between a franchiser and franchisee, Williams v. I.B. Fischer Nevada, 999 F.2d 445, 447-48 (9th Cir. 1993) (per curiam). See alsoLevi Case Co., Inc. v. ATS Prods. Inc., 788 F. Supp. 428, 431-32 (N.D. Cal. 1992) (holding that a patent holder was legally incapable of conspiring with the patent licensee).

Id. at 1034. See also Ultrasound Imaging Corp. v. The American Society of Breast Surgeons, 358 F. Supp. 2d 475 (D. Md. 2005) (nonprofit surgical association's decision not to permit plaintiff to exhibit its merchandise at defendant's annual conference was a unilateral act).. See also Webster County Memorial Hospital v. United Mine Workers of America Welfare \& Retirement Fund, 536 F.2d 419 (D.C. Cir. 1976). A labor union welfare fund provided health care for its members through contracts with hospitals and other providers of health care. The union ceased patronizing the plaintiff hospital pending resolution of a fee dispute. The hospital alleged a "boycott" conspiracy. Without characterizing the union as a single entity or the members as conspirators, the court held only that a conspiracy, if any, was not of the per se kind.

On the other side, see Freeman v. San Diego Assn. of Realtors, 322 F.3d 1133, 1144-1146 (9th Cir.), cert. denied, 540 U.S. 940 (2003) (mere fact that different real estate associations were engaged in production of a common MLS database did not render them a single entity with respect to claim that they fixed the price of individually provided support services for that database); National Hockey League Players Assn. v. Plymouth Whalers Hockey Club, 419 F.3d 462 (6th Cir. 2005) (NHL was composed of multiple teams and thus had conspiratorial capacity for purposes of its agreed-upon adoption of eligibility rules); American Needle, Inc. v. New Orleans Louisiana Saints, 496 F. Supp. 2d 941 (N.D. III. 2007), aff'd, 338 F. 3d 736(7th Cir. 2008), cert. granted, 2009 WL 1835175 (US Jun. 29, 2009) (NFL should be considered a single entity for purposes of claim that their jointly owned licensing affiliate granted an exclusive trademark license to a rival clothing manufacturer; following Chicago Professional Sports Ltd. Partnership v. National Basketball Assoc., 95 F.3d 593 (7th Cir. 1996)); Visa USA, Inc. v. First Data Corp., 2005-2 Trade Cas. $\mid 74,968$ (N.D. Cal. Aug. 16, 2005) (with respect to its network operating rules the Visa joint venture was not a single entity but rather a combination composed of its individual bank members; noting that the members did not have common ownership, were not fiduciaries of one another, did not share profits and losses, and had many divergent economic interests; further, they competed with each other in 
Feb., 2010

\section{Professional Sports Leagues}

Leagues of professional sports teams have faced considerable antitrust litigation over various (1) ethical rules governing players, (2) hiring rules affecting player eligibility for employment and competition among the teams for players,(3) rules governing team location and other team management decisions, and(4) rules governing a team owner's relation to other sports. Many league rules might be characterized as "boycotts," which are often said to be unlawful per se. Because it seems so obvious that such rules ought not to be condemned automatically - and they have not been-some courts and commentators sought to escape the per se claim by characterizing the league as a single entity. Many but not all courts have mainly rejected both the single entity and the per se claims, finding conspiracies and often condemning particular league rules as unreasonable.

In the Soccer case, for example, the Second Circuit considered a National Football League (NFL) rule forbidding owners of member teams from investing in other professional sports. ${ }^{21}$ The court reversed the district judge's holding that "\$1 does not apply for the reason that the NFL acted as a 'single economic entity' and not as a combination or conspiracy...."22 The Second Circuit relied on the Supreme Court's Timken language stating that creating a joint venture does not eliminate a conspiracy among the creators. ${ }^{23}$ To rule otherwise would, the Soccer case declared, create

[a] loophole [that] would permit league members to escape antitrust responsibility for any restraint entered into by them that would benefit their league or enhance their ability to compete even though the benefit would be outweighed by its anticompetitive effects. ${ }^{24}$

The quoted policy rationale might seem to beg the question, for anticompetitive effects resulting from unilateral action are not governed by Sherman Act §1. Nevertheless, that section should govern the league rule in dispute because Sherman Act §1 purported to control the behavior of team owners as independent actors in the investment market. The court suggested as much by analogizing the NFL's agreement with member teams to agreements between manufacturing firms and unrelated distributing firms, which the Sherman Act clearly covers. A better analysis would focus directly on the restraint on investors. We saw earlier that $\S 1$ applies to an agreement between an ordinary

many markets).

${ }^{21}$ North American Soccer League v. National Football League (Soccer), 670 F.2d 1249 (2d Cir.), cert. denied, 459 U.S. 1074 (1982). Accord Volvo N. Am. Corp. v. Men's Intl. Prof. Tennis Council, 857 F.2d 55 (2d Cir. 1988) (tennis association decisions represented conspiracy of members).

${ }^{22}$ Soccer, 670 F. 2d at 1256.

${ }^{23}$ On the Timken decision, see 7 Phillip E. Areeda \& Herbert Hovenkamp, Antitrust Law $\uparrow 1463 d$ (3d ed. 2010) (in press).

${ }^{24} 670$ F.2d at 1257. 
corporation and its shareholders in limiting their other investments. ${ }^{25}$

In this respect, as in player eligibility and hiring practices, the member teams remain significant economic actors. Not only is each an economic entity whose ownership interests are unrelated to those of other teams, but each generates its own profits (or losses), selects its own management, hires and fires, arranges its own home playing site, and the like. To be sure, some joint activity is essential to the operation of professional sports: game rules, schedules, playoff rules, revenue divisions among teams, and perhaps television rights and revenue allocations. The league thus has a dual personality. Like the New York Stock Exchange, it is an entity in its own right in some respects, but it also makes rules for its members' own marketplace behavior.

It may be helpful to compare a different structure. Imagine that investors create a new Hypothetical Football League (HFL); that the league is the only business entity involved; that it hires and fires and designates certain divisions to which it assigns and reassigns players and managers; that it decides how many teams to have, where to locate them, and when to move them; that it contracts with cities, stadiums, broadcasters, and so forth; and that it receives all the revenues, decides what to retain, and distributes the remainder to shareholders. The HFL would not be immune from Sherman Act §2. But apart from agreements limiting the opportunities of its investors, players, broadcasters, and so forth to deal with a rival league, the HFL would escape $\S 1$ in deciding to "boycott" teenagers, one-eyed players, or students still in college; to set salaries and assign or reassign players among its divisions; or to add, subtract, or relocate playing divisions. The courts have generally so held in the relatively few decisions involving sports league teams that are not individually owned but are the property of the league itself. ${ }^{26}$

But why should antitrust courts largely ignore the HFL while involving themselves so deeply in the affairs of the actual sports leagues? Are the HFL and the NFL so different? Perhaps it is enough to be grateful that professional sports have not been organized in the HFL way, which creates so much uncorrected power. Here, as elsewhere, we take industrial organization as we find it, and here we find entities with separate market significance, albeit entities that need more collaboration than we tolerate for ordinary business firms.

The courts have largely understood that sports leagues lie in between ordinary business firms, whose collaboration is suspect, and totally integrated enterprises subject only to §2. They have also understood that these situations need "in-between" substantive antitrust rules. They certainly, and correctly, have not woodenly applied the per se prohibitions developed for ordinary business

\footnotetext{
${ }^{25}$ See 7 Antitrust Law $\mid 1476 a$.

${ }^{26}$ E.g., Eleven Line v. North Texas State Soccer Assn., 213 F.3d 198, 205 (5th Cir. 2000), appeal after remand, 251 F. 3d 157 (5th Cir. 2001) (precluding conspiracy claim among the players and coaches of a not-for-profit soccer league whose teams were simply organized by the league itself, and not "owned" by any distinct entities). But see the discussion of the First Circuit's important Fraser decision, infra at notes 36-42.
} 
situations. But comprehensible guides to "reasonableness" have not yet emerged. The inherent openness of that term often leads judges and juries to venture beyond competition and into management discretion. The line between them has remained elusive for all of us.

In sum, the rules of a sports league should be regarded as "conspiratorial" when they affect the conduct of individual participants in their nonventure business but as unilateral when they have no such effect. For example, the NFL's decision to have a schedule consisting of 12 one-hour games per year is clearly an "output limitation," because it could have more or longer games, but it is also an essentially unilateral act because it affects nothing but the output of the NFL as an entity. By contrast, a rule stating that the NFL schedule consists of 12 games and that the individual team owners are forbidden from organizing additional games among NFL teams or between NFL and non-NFL teams should be regarded as collaborative, because it affects the individual members' nonventure conduct. Of course, such a rule might be "reasonable," and thus lawful, but it is not unilateral.

In Chicago Professional Sports the Seventh Circuit ultimately decided that, notwithstanding superficial similarities to the NCAA ${ }^{27}$ the NBA was more like a single entity than a cartel of independent teams. ${ }^{28}$ The district court had held that the NBA cannot be a single entity unless there was a "complete unity of interest," ${ }^{29}$ which the individual teams did not have because each was a separately owned profit-making entity. The NBA argued that it was an incorporated entity and that it should be treated as a corporate board, with the teams treated as the corporation's subsidiaries. Of course, this relationship is not the same as the parent-subsidiary relationship, for the teams are not commonly owned by their "parent." Nevertheless, it does produce a single product-namely, NBA basketball.

\section{The Seventh Circuit concluded:}

Copperweld...asks why the antitrust laws distinguish between unilateral and concerted action, and then assigns a parent-subsidiary group to the "unilateral" side in light of those functions. Like a single firm, the parent-subsidiary combination cooperates internally to increase efficiency. Conduct that "deprives the marketplace of the independent centers of decision-making that competition assumes," [Copperweld,] 467 U.S. at 769, without the efficiencies that come with integration inside a firm, go on the "concerted" side of the line. And there are entities in the middle: "mergers, joint ventures, and various vertical agreements"

\footnotetext{
${ }^{27}$ National Collegiate Athletic Assn. v. Board of Regents, 468 U.S. 85 (1984).

${ }^{28}$ Chicago Professional Sports Ltd. Partnership v. NBA, 95 F.3d 593 (7th Cir. 1996). See also See also American Needle, Inc. v. NFL, 538 F.3d 736 (7th Cir. 2008), cert. granted, 2009 WI 1835175 (US Jun. 9, 2009).

${ }^{29}$ See id. at 597; and 874 F. Supp. 844 (N.D. III. 1995).
} 
(id. at 768) that reduce the number of independent decision makers yet may improve efficiency. These are assessed under the Rule of Reason. We see no reason why a sports league cannot be treated as a single firm in this typology. It produces a single product; cooperation is essential (a league with one team would be like one hand clapping); and a league need not deprive the market of independent centers of decision making. ${ }^{30}$

While all of this would seem to apply equally to the NCAA case, where the court found an agreement of separate colleges and their football teams, the Seventh Circuit found this distinction:

[T] he NBA has no existence independent of sports. It makes professional basketball; only it can make "NBA Basketball" games; and unlike the NCAA the NBA also "makes" teams.... [T] he NBA created new teams in Toronto and Vancouver, stocked with players from the 27 existing teams plus an extra helping of draft choices. All of this makes the league look like a single firm. Yet the 29 clubs, unlike GM's plants, have the right to secede....and rearrange into two or three leagues. Professional sports leagues have been assembled from clubs that formerly belonged to other leagues.... Moreover, the league looks more or less like a firm depending on which facet of the business one examines. From the perspective of fans and advertisers (who use sports telecasts to reach fans), "NBA Basketball" is one product from a single source..., just as General Motors is a single firm even though a Corvette differs from a Chevrolet. But from the perspective of college basketball players who seek to sell their skills, the teams are distinct.... 32

The Seventh Circuit would thus extend Copperweld to situations where a second corporation is separately owned but was created by the first corporation-at least for some purposes. The colleges in NCAA were unquestionably separate entities with significant functions outside of the NCAA, thus justifying their treatment as distinct. By contrast, a professional sports team typically has no other function than the provision of professional sports and, as

\footnotetext{
${ }^{30}$ Chicago Professional Sports, 95 F.3d at 598-599.

${ }^{32} 95 \mathrm{~F} .3 \mathrm{~d}$ at 599. The court also likened the NBA to a franchise system, whose many business decisions are undertaken for the group as a whole; for example, we would not expect to see one McDonald's franchise compete with the others by offering pizza. Id. at 598. Of course, an important difference in the franchise setting is that the relevant agreement is presumably a vertical one between the franchiser and each franchisee separately. Antitrust would certainly look quite closely at a horizontal agreement among a group of restaurants that none would sell pizza, even if the restaurants shared certain intellectual property such as a common name.
} 
the court pointed out, the creation of many of the separate teams is actually instigated by the parent organization. ${ }^{33}$

The point can be pushed too far. Many firms spun off from other firms subsequently become competitors and are quite clearly capable of collusion. The important additional point in the NBA situation is that not only were the individual teams created by the organization, they were also created exclusively for the purpose of supplying professional basketball within the ongoing, network-style NBA joint venture.

But suppose that at some later time, after relaxation of NBA rules limiting collateral activities, two or more of these NBA teams individually entered into the manufacture of sporting goods such as basketballs. The Seventh Circuit's rationale would not protect a subsequent price-fixing agreement in basketballs, because the teams were not created for that purpose and would thus have to be regarded as distinct entities. Further, basketball production differs from basketball game production in that the former does not require an ongoing network joint venture. The Chicago Professional Sports rule must be limited to activities for which the joint venture is reasonably necessary. ${ }^{34}$

The Seventh Circuit's approach seems to understate the relevance of concerted activity in a rule of reason case. Once the tribunal has concluded that the NBA is a single entity, then its output limitation (unaccompanied by any exclusionary practice directed at others) must be considered legal per se and not subjected to the rule of reason. ${ }^{35}$ We would prefer to focus on the particular rule under antitrust scrutiny. If it affected the individual teams' nonventure conduct it should be regarded as collaborative; if it did not, then it should be considered unilateral.

The American Needle decision, currently before the Supreme Court,

${ }^{33}$ See also NFL v. North Am. Soccer League, 459 U.S. 1074, 1077 (1982) (Rehnquist, J., dissenting from certiorari denial, arguing that NFL should be treated as single entity); Seabury Management v. PGA of Am., 878 F. Supp. 771 (D. Md. 1994), aff'd in relevant part, 52F.3d 322 (4th Cir. 1995), cert. denied, 516 U.S. 867 (1995) (treating PGA as single entity).

${ }^{34}$ Thus, the court issued this warning:

Sports are sufficiently diverse that it is essential to investigate their organization and ask Copperweld's functional question one league at a time - and perhaps one facet of a league at a time, for we do not rule out the possibility that an organization such as the NBA is best understood as one firm when selling broadcast rights to a network in competition with a thousand other producers of entertainment, but is best understood as a joint venture when curtailing competition for players who have few other market opportunities.

95 F.3d at 600 .

${ }^{35}$ See 3A Phillip E. Areeda and Herbert Hovenkamp Antitrust Law \720 (3d ed. 2008). 
Feb., 2010

involves the NFL's exclusive license agreement, not of the NFL's own independent intellectual property, but rather of the intellectual property of the individual teams. The NFL had acquired an exclusive right from the individual teams to license these rights, mainly in trademarked symbols that were placed on clothing, helmets and hats (headware) sold for consumer use, and other goods bearing the trademarks of the individual NFL teams. The NFL then in turn granted an exclusive license to Rebook for headware, thus making it impossible for the plaintiff American Needle to acquire such rights. ${ }^{2}$

In this case the individual team members were giving up their individual right to license their trademarked symbols individually, and competitively, in favor of the NFL's exclusive license. The ancillary restraints doctrine is an inherently better vehicle for assessing such claims, and characterization of the conduct as "unilateral" largely preclude such analysis. The NFL has legitimate interests in managing the NFL schedule and game rules, regulations, contracts that inherently involve two or more member teams, such as broadcasting agreements, and the like. With respect to individually held trademarks it may also have an interest in the manner in which they are licensed - for example, if they are licensed by an individual team for use on articles that are offensive or that denigrate the NFL or tarnish its image. Whether it should have the authority to eliminate all inter-team competition in trademark licensing is a different issue, and one which the doctrine of ancillary joint venture restraints is designed to address. By contrast, to the extent that the NFL developed its own trademarks, held by and representing the NFL as an organization, no team individually could individually license that right and an exclusive license granting reproduction rights to another would have to be counted as a unilateral act. By the same token, if the issue were labor negotiations the NFL would be a single entity with respect to its own employees, namely those of the NFL itself; but it would be and has been considered to be a collaboration of multiple employers with respect to the employees, including players, of its individual teams. ${ }^{3}$

In sharp contrast to Chicago Professional Sports, dicta in the First Circuit's Fraser decision found conspiratorial capacity notwithstanding common ownership. ${ }^{36}$ Defendant Major League Soccer (MLS) is the only professional soccer league in the United States sanctioned for World Cup play. MLS is itself owned by a number of independent investors, and it owns all of the 12 participating teams. Some of the investors are passive; others are active as individual team "managers." The court described the role of these investor managers:

MLS contracts with these investors to operate nine of the league's teams .the league runs the other three). These

${ }^{2}$ American Needle, Inc. v. NFL, 538 F.3d 736 (7th Cir. 2008), cert. granted, 2009 WI 1835175 (US Jun. 9, 2009).

${ }^{3}$ Brown v. Pro Football, Inc., 518 U.S. 231, 249 (1996).

${ }^{36}$ Fraser v. Major League Soccer, 284 F.3d 47 (1st Cir. 2002), cert. denied, 537 US 885 (2002). 
investors are referred to as operator/investors and are the co-defendants in this action. Each operator/investor has the "exclusive right and obligation to provide Management Services for a Team within its Home Territory" and is given some leeway in running the team and reaping the potential benefits therefrom.

Specifically, the operator/investors hire, at their own expense and discretion, local staff(including the general managers and coaches of their respective teams), and are responsible for local office expenses, local promotional costs for home games, and one-half the stadium rent (the same portion as MLS). In addition, they license local broadcast rights, sell home tickets, and conduct all local marketing on behalf of MLS; agreements regarding these matters do not require the prior approval of MLS. And they control a majority of the seats on MLS's board, the very same body which runs the league's operations. Among other things, the board is responsible for hiring the commissioner and approving national television contracts and marketing decisions, league rules and policies(including team player budgets), and sales of interests.

The operator/investors also play a limited role in selecting players for their respective teams. While the operating agreements provide that the operator/investors will not bid independently for players against MLS, they may trade players with other MLS teams and select players in the league's draft. Such transactions, however, must follow strict rules established by the league. Most importantly, no team may exceed the maximum player budget established by the management committee.

In return for the services of the operator/investors, MLS pays each of them a "management fee" that corresponds (in large part) to the performance of their respective team....

... Although the league retains legal title to the teams, the operator/investors may transfer their operating rights, within certain limits, and retain much of the value created by their individual efforts and investments. Investors may transfer their ownership stakes and operating rights to other current investors without obtaining prior consent; transfers to outside investors, however, require a two-thirds majority vote of the board. ${ }^{37}$

The First Circuit concluded that on these facts MLS should be considered a

\footnotetext{
${ }^{37}$ Id. at 54.
} 
Feb., 2010

group of separate teams capable of conspiring, rather than a single entity. The court acknowledged that in a more straightforward situation, where a league owned and centrally managed all the teams, a single-entity conclusion would be mandated. ${ }^{38}$ However,

The challenge here is primarily to the operator/investors' role as team managers, not as ordinary stockholders, and to restrictions imposed on them in that role preventing competition for player services. That a stockholder may be insulated by Copperweld when making ordinary governance decisions does not mean automatic protection when the stockholder is also an entrepreneur separately contracting with the company. Above all, there are functional differences between this case and Copperweld that are significant for antitrust policy....

... MLS and its operator/investors have separate contractual relationships giving the operator/investors rights that take them part way along the path to ordinary sports team owners: they do some independent hiring and make out-of-pocket investments in their own teams; they retain a large portion of the revenues from the activities of their teams; and each has limited sale rights in its own team that relate to specific assets and not just shares in the common enterprise. $^{39}$

Further,

in this case the analogy to a single entity is weakened, and the resemblance to a collaborative venture strengthened, by the fact that the operator/investors are not mere servants of MLS; effectively, they control it, having the majority of votes on the managing board. The problem is especially serious where, as here, the stockholders are themselves potential competitors with MLS and with each other. Here, it is MLS that has two roles: one as an entrepreneur with its own assets and revenues; the other (arguably) as a nominally vertical device for producing horizontal coordination, i.e., limiting competition among operator/investors. ${ }^{40}$

Thus, the court described the situation as similar to the one in Sealy, ${ }^{41}$ in which the Sealy joint venture's name and intellectual property were owned by

${ }^{38}$ Cf. Eleven Line v. North Texas State Soccer Assn., 213 F.3d 198, 205 (5th Cir. 2000), appeal after remand, 251 F. 3d 157 (5th Cir. 2001).

${ }^{39}$ Fraser, 284 F.3d at 57.

${ }^{40}$ Ibid.

${ }^{41}$ Id. at 215, citing United States v. Sealy Corp., 388 U.S. 350 (1967); Topco Assocs. v. United States, 405 U.S. 596 (1972).. 
Feb., 2010

independent bedding manufacturers. Sealy then licensed each of the manufacturers to produce under the Sealy name in exclusive territories, and the Supreme Court found a horizontal territorial division scheme notwithstanding that the market division emanated from a single "firm."

Nevertheless, the First Circuit ultimately found for the defendants because the plaintiffs had failed to prove a relevant market. ${ }^{42}$

${ }^{42}$ Fraser v. Major League Soccer, 284 F.3d 47, 59-61 (1st Cir. 2002), cert. denied, 537 US 885 (2002).. 